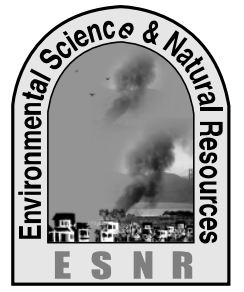

\title{
Heavy Metal Contamination in Farm and Urban Soil in Mymensingh
}

\author{
A. H. M. M. Morshed, M. A. Farukh and M. A. Sattar \\ Department of Environmental Science, \\ Bangladesh Agricultural University, Mymensingh-2202, Bangladesh
}

\begin{abstract}
A study was carried out to determine the status of heavy metals in farm and urban soils from intensively growing areas of Mymensingh. Sixty three soil samples were collected from 11 upazillas of Mymensingh. From these samples total amount of heavy metals like $\mathrm{Pb}, \mathrm{Cd}, \mathrm{Ni}, \mathrm{Cr}, \mathrm{Fe}$ and $\mathrm{Mn}$ were tested. The soils were also analyzed for texture, $\mathrm{pH}$ and organic matter content. The mean concentrations of $\mathrm{Pb}, \mathrm{Cd}, \mathrm{Ni}, \mathrm{Cr}, \mathrm{Fe}$ and $\mathrm{Mn}$ in farm soils were 19.64, 0.32, 39.80, 14.10, 1800.40, 135.66 $\mu \mathrm{g} \mathrm{g}^{-1}$, respectively and the mean concentrations of above metals in urban soils were $20.93,0.37,36.90,28.85,1810.08,127.05 \mu \mathrm{g} \mathrm{g}^{-1}$, respectively. The heavy metal concentrations in farm soils were within the limit allowed for maximum acceptable concentration for satisfactory crop production. Heavy metals in urban soils were also below the limit considered as contaminated soil. Most of the heavy metals in both farm and urban soils were negatively correlated with sand and positively correlated with silt. There was no significant correlation between heavy metal content and soil $\mathrm{pH}$ or organic matter in both farm and urban soils with very few exceptions. Most of the heavy metals did not show any significant correlation with each other expect Fe which showed significant correlation with $\mathrm{Pb}, \mathrm{Ni}, \mathrm{Cr}, \mathrm{Mn}$ and $\mathrm{Cd}$ for both farm and urban soils.
\end{abstract}

Key words: Contamination, Correlation, Farm and urban soil, Heavy metals

\section{Introduction}

Heavy metals possess a great concern for contamination of soil and water because they are persistent and may affect vegetables, plant and human health. The "heavy metal" is generally a collective term, which applies to the group of metals and metalloids with atomic density greater than $4 \mathrm{gcm}^{-3}$ or 5 times or more greater than water (Huton and Symon, 1986; Hawkes, 1997). The heavy metals are widely distributed throughout the environment. Industrial discharge, fertilizer, manure, pesticide, fossil fuel, municipal waste, sewage-sludge, mining waste, animal waste, contaminated water etc. might be some of the major sources of heavy metal contamination in soil and water (Alloyway et al., 1988). When an element enters into the environment, it follows some biochemical cycles being transported by air, water and gravity until they reach a geochemical sink. Soil is the ultimate sink for all elements where heavy metals may accumulate in soil with a short span of time (Kabata and Pendias, 1992). The use of chemical fertilizers is now widespread for supplementing nutrients. Some phosphatic fertilizers and pesticides are also adding various types of heavy metals like $\mathrm{Cd}, \mathrm{Pb}$ and $\mathrm{Zn}$ as impurities (Alloway et al., 1988), which after application may significantly increase their content in the soil. It is reported that the major source of $\mathrm{Pb}$ intake for human being is food where the major absorption takes place in gastrointestinal tract (WHO, 1972). It is obvious that heavy metals at contamination level can cause detrimental effect on crop production and health. The present study was therefore undertaken with the objectives to determine $\mathrm{Pb}, \mathrm{Cd}, \mathrm{Ni}, \mathrm{Cr}, \mathrm{Fe}$ and $\mathrm{Mn}$ contaminations in 11 upazillas of Mymensingh to assess the existing heavy metal contamination status.

\section{Materials and Methods}

A study was conducted during January to March 2012 to determine the status of heavy metals in farm and urban soils of intensively growing areas of Mymensingh. Farm soil samples were collected from 11 upazillas of Mymensingh namely Trishal, Gouripur, Bhaluka, Tarakanda, Ishwargonj, Phulpur, Haluaghat, Muktagacha, Goforgaon, Nandail, Mymensingh Sadar. Urban soil samples were collected from 9 locations namely Kalibari drain soil, Ganginarpar drain soil, Town Hall drain soil, Kalibari roadside soil, Ganginarpar roadside soil,Town Hall roadside soil, Tangail busstand soil, Maskanda busstand soil and Bridge busstand soil of Mymensingh town. Farm soils were collected at a depth of $0-15 \mathrm{~cm}$ from paddy fields of each location. Plant roots and other extraneous materials were removed from the collected soil samples, air-dried, ground and passed through $2 \mathrm{~mm}$-mesh sieve. The samples were kept in plastic container. Collected samples were further analyzed for physical characteristics namely percentage of sand, silt, clay, and textural class and chemical characteristics such as soil $\mathrm{P}^{\mathrm{H}}$ and organic carbon. To determine the total $\mathrm{Pb}$, $\mathrm{Cd}, \mathrm{Ni}, \mathrm{Cr}, \mathrm{Fe}$ and $\mathrm{Mn}$ the soil samples were then 
digested with di-acid mixture $\left(\mathrm{HNO}_{3}\right.$ and $\left.\mathrm{H}_{2} \mathrm{O}_{2}\right)$ at digestion laboratory, Dept. of Soil Science, Bangladesh Agricultural University, Mymensingh. The total concentration of $\mathrm{Pb}, \mathrm{Cd}, \mathrm{Ni}, \mathrm{Cr}, \mathrm{Fe}$ and $\mathrm{Mn}$ were determined at the laboratory of soil science of Bangladesh Rice Research Institute, Gazipur by using the Atomic Absorbtion Spectrophotometer (AAS). Therefore, the range, mean and standard deviation of the contents of heavy metals of soils were calculated. Correlation statistics was done to examine the interrelationship among the heavy metals with soil $\mathrm{pH}$, organic matter and texture.

\section{Results and discussion}

\section{Heavy metal status}

\section{A. Farm soils}

All the soils contain below or within the limit of Maximum Allowable Concentrations (MAC) for $\mathrm{Pb}$ $\left(20-300 \mathrm{mg} \mathrm{kg}^{-1}\right), \mathrm{Cd}\left(1\right.$ to $\left.5 \mathrm{mg} \mathrm{kg}^{-1}\right), \mathrm{Ni}(20-60$ $\left.\mathrm{mg} \mathrm{kg}^{-1}\right), \mathrm{Cr}\left(50-200 \mathrm{mg} \mathrm{kg}^{-1}\right)$ and $\mathrm{Mn}(1500-3000)$ $\mathrm{mg} \mathrm{kg}^{-1}$ in agricultural soils (Table 1.). The concentrations of the elements were also within typical values for uncontaminated soil range such as $\mathrm{Pb}\left(0-500 \mathrm{mg} \mathrm{kg}^{-1}\right), \mathrm{Cd}\left(0\right.$ to $\left.1 \mathrm{mg} \mathrm{kg}^{-1}\right), \mathrm{Ni}(20-50$ $\left.\mathrm{mg} \mathrm{kg}^{-1}\right), \mathrm{Cr}\left(0-100 \mathrm{mg} \mathrm{kg}^{-1}\right)$ and $\mathrm{Mn}\left(0-500 \mathrm{mg} \mathrm{kg}^{-}\right.$ 1) (Table 1.).

Table 1. Total $\mathrm{Pb}, \mathrm{Cd}, \mathrm{Ni}, \mathrm{Cr}, \mathrm{Fe}$ and $\mathrm{Mn}$ concentrations in farm soils of Mymensingh

\begin{tabular}{|c|c|c|c|c|c|c|c|}
\hline \multirow{2}{*}{$\begin{array}{l}\text { SL. } \\
\text { No. }\end{array}$} & \multirow[t]{2}{*}{ Sample site } & $\mathrm{Pb}$ & $\mathrm{Cd}$ & $\mathrm{Ni}$ & $\mathrm{Cr}$ & $\mathrm{Fe}$ & $\mathrm{Mn}$ \\
\hline & & \multicolumn{6}{|c|}{ Concentration $\left(\mu \mathrm{g} \mathrm{g}^{-1}\right)$} \\
\hline 1 & Trishal & 18.40 & 0.20 & 12.40 & 3.90 & 1811.10 & 173.70 \\
\hline 2 & Gouripur & 26.40 & 0.27 & 32.20 & 14.60 & 1793.20 & 134.50 \\
\hline 3 & Bhaluka & 16.80 & $\mathbf{0 . 1 7}$ & 22.40 & 41.10 & 1866.20 & 140.60 \\
\hline 4 & Tarakanda & 18.40 & 0.32 & 24.60 & 18.60 & 1859.70 & 123.80 \\
\hline 5 & Ishwargonj & 17.70 & 0.38 & 30.60 & 8.60 & 1748.00 & 143.10 \\
\hline 6 & Phulpur & 17.00 & 0.34 & 42.70 & 10.30 & $\mathbf{1 7 2 1 . 8 0}$ & 137.60 \\
\hline 7 & Haluaghat & 16.80 & 0.18 & 27.20 & 10.00 & 1777.00 & 114.20 \\
\hline 8 & Muktagacha & 19.00 & 0.42 & 31.40 & 12.00 & 1773.70 & 125.10 \\
\hline 9 & Goforgaon & 21.90 & 0.19 & 38.80 & 11.40 & 1890.50 & 136.10 \\
\hline 10 & Nandail & 24.20 & 0.32 & 19.50 & 14.00 & 1798.00 & 123.60 \\
\hline 11 & Mymensingh Sadar & 19.50 & 0.68 & 36.00 & 10.60 & 1765.60 & 140.00 \\
\hline & Mean & 19.64 & $\mathbf{0 . 3 2}$ & 28.89 & 14.10 & 1800.40 & 135.66 \\
\hline & Standard deviation & 3.19 & 0.15 & 9.90 & 9.69 & 52.47 & 15.52 \\
\hline & MAC $^{1}$ & $20-300$ & 1-5 & $20-60$ & $50-200$ & - & $1500-3000$ \\
\hline Typic & values for uncontaminated soil $^{2}$ & $0-500$ & $0-1$ & 0-20 & 0-100 & - & $0-500$ \\
\hline
\end{tabular}

${ }^{1}$ Kabata-Pendias, 2001 ; Sadurski, 2004, ${ }^{2}$ Sattar, 1996

\section{B. Urban soils}

All the soils contain below or within typical values for uncontaminated soil range such as $\mathrm{Pb}(0-500 \mathrm{mg}$ $\left.\mathrm{kg}^{-1}\right), \mathrm{Cd}\left(0\right.$ to $\left.1 \mathrm{mg} \mathrm{kg}^{-1}\right), \mathrm{Ni}\left(20-50 \mathrm{mg} \mathrm{kg}^{-1}\right), \mathrm{Cr}(0-$ $\left.100 \mathrm{mg} \mathrm{kg}^{-1}\right)$ and $\mathrm{Mn}\left(0-500 \mathrm{mg} \mathrm{kg}^{-1}\right)$ (Table 2.)

Table 2. Total $\mathrm{Pb}, \mathrm{Cd}, \mathrm{Ni}, \mathrm{Cr}, \mathrm{Fe}$ and $\mathrm{Mn}$ concentrations in urban soils of Mymensingh

\begin{tabular}{|c|c|c|c|c|c|c|c|c|}
\hline \multirow{2}{*}{$\begin{array}{l}\text { SL. } \\
\text { No. }\end{array}$} & \multirow[t]{2}{*}{ Sample site } & \multirow[t]{2}{*}{ Soil Types } & $\mathrm{Pb}$ & $\mathrm{Cd}$ & $\mathrm{Ni}$ & $\mathrm{Cr}$ & $\mathrm{Fe}$ & $\mathrm{Mn}$ \\
\hline & & & \multicolumn{6}{|c|}{ Concentration $\left(\mu \mathrm{g} \mathrm{g}^{-1}\right)$} \\
\hline 1 & Kalibari & $\mathrm{DS}^{1}$ & 23.13 & 0.26 & 39.80 & 3.10 & 1822.40 & 128.00 \\
\hline 2 & Ganginarpar & DS & 22.93 & 0.35 & 42.70 & 12.90 & 1867.30 & 128.98 \\
\hline 3 & Town Hall & DS & 25.65 & 0.17 & 95.70 & 95.60 & 1853.20 & 125.08 \\
\hline 4 & Kalibari & $\mathrm{RSS}^{2}$ & 17.17 & 0.28 & 36.30 & 67.00 & 1736.40 & 152.30 \\
\hline 5 & Ganginarpar & RSS & 14.30 & 0.46 & 10.70 & 17.80 & 1772.10 & 121.78 \\
\hline 6 & Town Hall & RSS & 14.18 & 0.58 & 34.30 & 14.90 & 1765.60 & 125.08 \\
\hline 7 & Tangail & $\mathrm{BSS}^{3}$ & 25.33 & 0.48 & 13.10 & 28.40 & 1729.40 & 127.70 \\
\hline 8 & Maskanda & $\mathrm{BSS}$ & 23.92 & 0.52 & 21.0 & 10.00 & 1854.30 & 120.65 \\
\hline 9 & Bridge & BSS & 21.80 & 0.24 & 38.5 & 10.00 & 1896.50 & 113.90 \\
\hline \multicolumn{3}{|c|}{ Mean } & 20.93 & 0.37 & 36.90 & 28.85 & 1810.80 & $\mathbf{1 2 7 . 0 5}$ \\
\hline \multicolumn{3}{|c|}{ Standard deviation } & 4.52 & 0.14 & 25.03 & 31.33 & 61.30 & 10.56 \\
\hline \multicolumn{3}{|c|}{ Typical values for uncontaminated soil ${ }^{4}$} & $0-500$ & 0-1 & 0-20 & 0-100 & - & $0-500$ \\
\hline
\end{tabular}

${ }^{1} \mathrm{DS}=$ Drain soils, ${ }^{2} \mathrm{RSS}=$ Roadside Soils, ${ }^{3} \mathrm{BSS}=$ Bus Stand Soil, ${ }^{4}$ Sattar, 1996

Interrelationships among heavy metals of soils 


\section{A. Farm soils:}

Table 3. Correlation among heavy metals of farm soils

\begin{tabular}{|l|l|l|l|l|l|l|}
\hline Elements & $\mathrm{Pb}$ & $\mathrm{Cd}$ & $\mathrm{Ni}$ & $\mathrm{Cr}$ & $\mathrm{Fe}$ & $\mathrm{Mn}$ \\
\hline $\mathrm{Pb}$ & - & 0.01 & -0.03 & -0.12 & 0.16 & -0.12 \\
\hline $\mathrm{Cd}$ & - & - & -0.29 & -0.27 & -0.50 & -0.05 \\
\hline $\mathrm{Ni}$ & - & - & - & 0.51 & 0.57 & -0.02 \\
\hline $\mathrm{Cr}$ & - & - & - & - & 0.50 & -0.17 \\
\hline $\mathrm{Fe}$ & - & - & - & - & - & 0.02 \\
\hline $\mathrm{Mn}$ & - & - & - & - & - & - \\
\hline
\end{tabular}
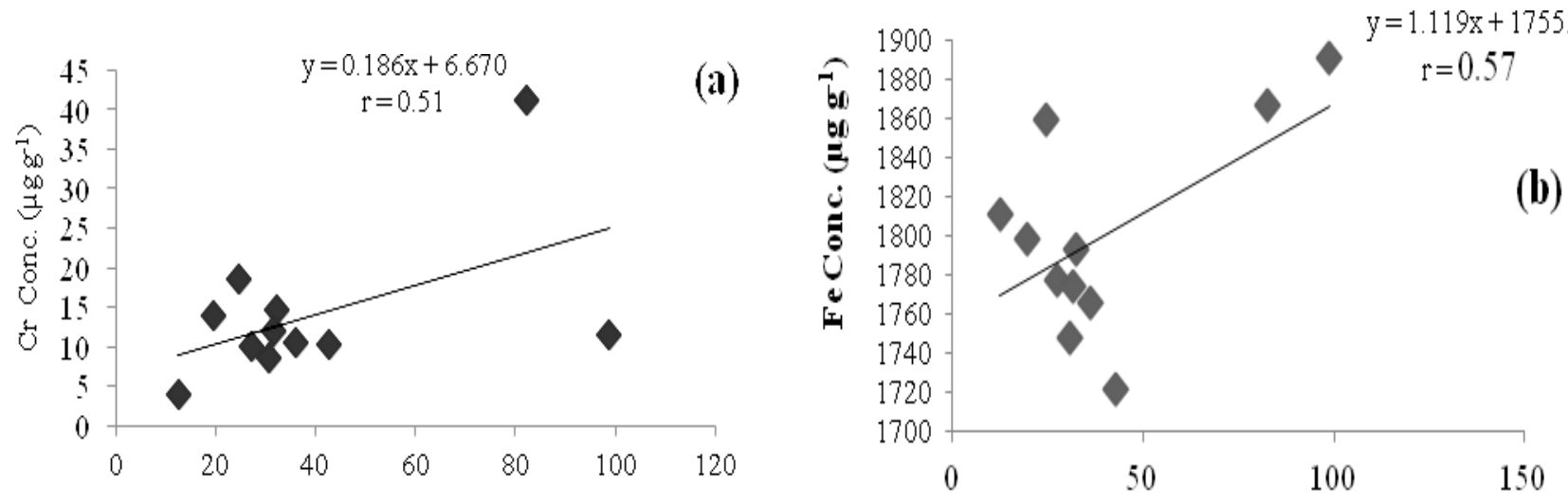

Ni Conc. (ug $\left.g^{\mathbf{l}}\right)$

Ni Conc. $\left(\mu \mathbf{g} \mathbf{g}^{\mathbf{l}}\right)$

Fig. Correlation between $\mathrm{Cr}$ and $\mathrm{Ni}(\mathrm{a})$ and $\mathrm{Ni}$ and $\mathrm{Cd}(\mathrm{b})$ in urban soils

\section{B. Urban Soils}

Table 4. Correlation among heavy metals of urban soils

\begin{tabular}{|c|c|c|c|c|c|c|}
\hline Elements & $\mathrm{Pb}$ & $\mathrm{Cd}$ & $\mathrm{Ni}$ & $\mathrm{Cr}$ & $\mathrm{Fe}$ & $\mathrm{Mn}$ \\
\hline $\mathrm{Pb}$ & - & -0.40 & 0.38 & 0.15 & 0.46 & -0.20 \\
\hline $\mathrm{Cd}$ & - & - & -0.71 & -0.50 & -0.43 & -0.17 \\
\hline $\mathrm{Ni}$ & - & - & - & 0.70 & 0.44 & 0.04 \\
\hline $\mathrm{Cr}$ & - & - & - & - & -0.16 & 0.47 \\
\hline $\mathrm{Fe}$ & - & - & - & - & - & -0.59 \\
\hline $\mathrm{Mn}$ & - & - & - & - & - & - \\
\hline
\end{tabular}



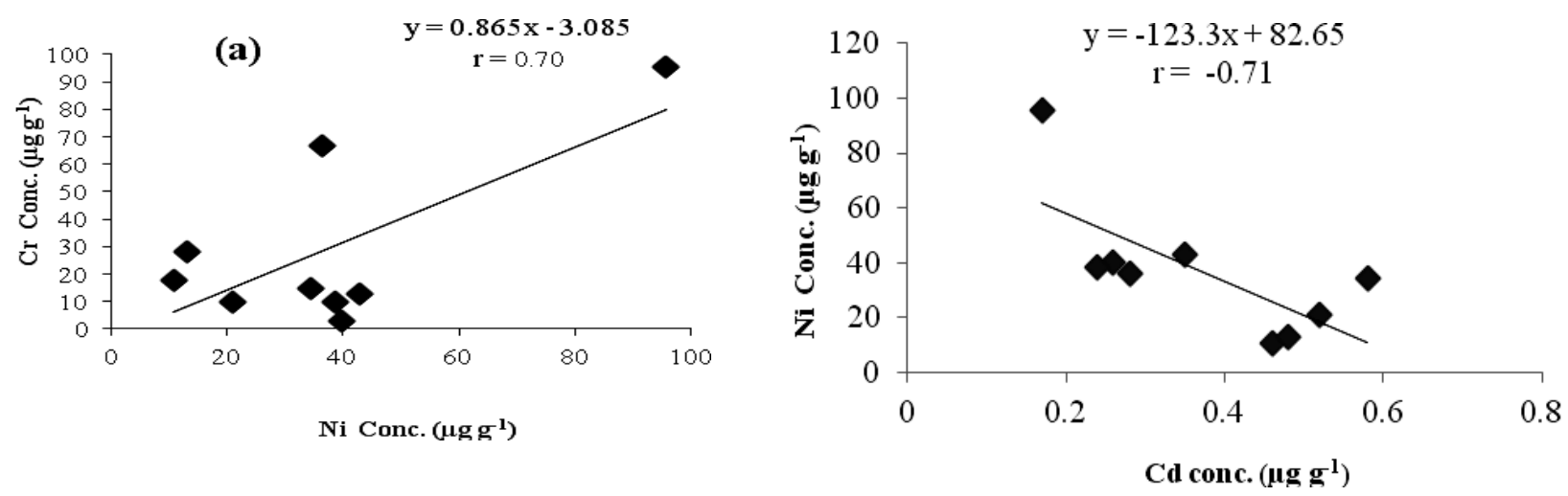

Fig. Correlation between $\mathrm{Cr}$ and $\mathrm{Ni}(\mathrm{a})$ and $\mathrm{Ni}$ and $\mathrm{Cd}(\mathrm{b})$ in urban soils

The negative correlation occurs because combined physiological effect of two or more elements is less than the sum of their independent effects, and positive correlation occurs because the combined effect of these elements is greater. (Olsen, 1972; Foy et al., 1978).

\section{Conclusions}

Heavy metals and its contamination is not a familiar term among the farmers of Bangladesh, even they actually don't aware of any kinds of contaminations or pollutions that can reduce their crop production and cause detrimental effect on health. So how they can protect these contaminations, while they don't know about it? At first they are to inform about these contaminations, especially how they take place. Awareness should build up about these contaminations so that they themselves can protect this hazard. Department of Agricultural Extension (DAE) and Department of Environmental Science can play very crucial role in this regard. Integrated Pest Management (IPM) can be another vital alternative to chemical fertilizers and pesticides to minimize the rate of contamination. Organic farming should be popularizing among the farmers. Dumping of municipal waste, sewage sludge, industrial sludge and effluents, chemicals from the laboratories shouldn't be disposed near to crop land.

However, findings of this study indicate that no element exceeded the maximum acceptable concentration (MAC) for crop production or below the contamination level for soils and for crop production.

\section{References}

Alloway, B. J.; Thornton, I.; Smart, G. A.; Sherlock, J. C. and Quinn, M. J. 1988. Metals
Availability. Total Environmental Science. $75: 41-69$.

Foy, C. D.; Chaney, R. L. and White, M. C. The physiology of metal toxicity in plants, Annu. Rev.Physiol., 29, 511, 1978.

Hawkes, J. S. 1997. Heavy Metals. J. Chem. Educ.. 74(11): 1374.

Hutton, M. and Symon, C. 1986. The Quantities of Cadmium, Lead, Mercury and Arsenic Entering the U.K. Environment from Human Activities. Sci. Total Environ. 57: 129-150.

Kabata-Pendias A. and Sadurski W. 2004. Trace elements and compounds in soil. In: Elements and Their Compounds in the Environment, 2 eds. E. Merian, M. Anke, M. Ihnat, M. Stoeppler, 79-99, Wiley-VCH, Weinheim.

Kabata-Pendias, A. 2011. Trace Elements in Soils and Plant. $4^{\text {th }}$ ed., CRC press, Boca Raton. pp. 24, 105, 115 .

Olsen, S. R.; Micronutrient interactions, in Micronutrients in Agriculture. Mortvedt, J. J.; Giordano, P. M.; and Lindsay, W. L.; eds., Soil Science Society of America, Madison. WI. 243, 1972.

Sattar, M. A. 1996. A textbook of environmental science (part 1). Mymensingh.119p.

World Health Organization (WHO). 1972. Health Hazards of the human nutrition. WHO, Geneva. 178.p 